\title{
MOLECULAR EVALUATION OF ANTISTAPHYLOCOCCAL SECONDARY METABOLITES OF BACTERIAL ISOLATES FROM HOSPITAL WASTEWATER ENVIRONMENT
}

\author{
PETHANNAN RAJA RAJAN ${ }^{1 *}$, MALLA SUDHAKAR ${ }^{2}$, BHASKAR ${ }^{1}$, ANUBROTO GOSH $^{1}$, SACHIN KARMAKAR \\ ${ }^{1}$ Department of Microbiology, Indian Academy Centre for Research and Post Graduate Studies, Bengaluru, Karnataka, India. \\ ${ }^{2}$ Department of Biotechnology, Indian Academy Centre for Research and Post Graduate Studies, Bengaluru, Karnataka, India. \\ Email: rajarajanbioscience@gmail.com
}

Received: 07 February 2017, Revised and Accepted: 28 March 2017

ABSTRACT

Objective: Antibiotics revolutionized medicine in the $20^{\text {th }}$ century, and have together with vaccination led to the near eradication of diseases such as tuberculosis in the developed world. Their effectiveness and easy access led to overuse, especially in livestock raising, prompting bacteria to develop resistance. The lantibiotics form a particular group among the antimicrobial peptides and are characterized by unique structural features. They are produced by a group of bacteria against some gram-positive bacteria. The present study was designed to screen for the lantibiotic producing organisms from the hospital samples.

Methods: The bacterial isolates were identified based on Bergey's manual of bacteriology and screened for the epidermin gene by polymerase chain reaction amplification.

Results: Of the 21 isolates screened, only 10 of them showed positive amplification for the epigene. Based on the biochemical characteristics, the isolates obtained were identified and labeled.

Conclusion: Further study on the purification of the compound need to be done. Some bacterial samples may not have the epidermin gene which does not show amplification, this confers that the epidermin gene is absent in certain organisms.

Keywords: Antibiotic resistance, Lantibiotics, Epidermin gene, Gram-positive bacteria.

(C) 2017 The Authors. Published by Innovare Academic Sciences Pvt Ltd. This is an open access article under the CC BY license (http://creativecommons. org/licenses/by/4. 0/) DOI: http://dx.doi.org/10.22159/ajpcr.2017.v10i6.17560

\section{INTRODUCTION}

Antibiotics, also called antibacterials, are a type of antimicrobial drugs used in the treatment and prevention of bacterial infection [1]. They may either kill or inhibit the growth of bacteria. A limited number of antibiotics also possess antiprotozoal activity. Antibiotics are not effective against viruses such as the common cold or influenza, and may be harmful when taken inappropriately [2].

The emergence of resistance of bacteria to antibiotics is a common phenomenon [3]. Emergence of resistance often reflects evolutionary processes that take place during antibiotic therapy [4,5]. The antibiotic treatment may select for bacterial strains with physiologically or genetically enhanced capacity to survive high doses of antibiotics. Under certain conditions, it may result in the preferential growth of resistant bacteria while growth of susceptible bacteria is inhibited by the drug. Antibacterial resistance may impose a biological cost, thereby reducing fitness of resistant strains, which can limit the spread of antibacterial-resistant bacteria, for example, in the absence of antibacterial compounds [6-8].

This article treats the terms as synonymous and according to the most widespread definition of antibiotics being a substance used against bacteria [3,9]. Lantibiotics are a class of peptide antibiotics produced by a large number of gram-positive bacteria such as Streptococcus and Streptomyces to attack other gram-positive bacteria and contain the characteristic polycyclic thioether amino acids lanthionine or methyllanthionine, as well as the unsaturated amino acids dehydroalanine and 2-aminoisobutyric acid [10]. It is composed of two alanine residues that are cross-linked on their $\beta$-carbon atoms by a thioether (monosulfide) linkage [11].

The lantibiotics are a class of more extensively modified bacteriocins, also called Class I bacteriocins $[12,13]$. (Bacteriocins for which disulfide bonds are the only modification to the peptide are Class II bacteriocins. Lantibiotics are well studied because of the commercial use of these bacteria in the food industry for making dairy products such as cheese $[14,15]$. Nisin and epidermin are members of a family of lantibiotics that bind to lipid II, a cell wall precursor lipid component of target bacteria and disrupt cell wall production [16]. All lantibiotics that have been characterized with respect to the stereochemistry of the thioether linkage contain $(2 S, 6 \mathrm{R})$-lanthionines, with many family members also containing $(2 S, 3 S, 6 R)-3$-methyllanthionines [17-19]. In addition, they generally (but not always) contain the unsaturated amino acids 2, 3-dehydroalanine and (Z)-2, 3-dehydrobutyrine [20]. In all, no $<15$ different posttranslational modifications have been identified in lantibiotics and it is likely that other modifications remain to be discovered. These modifications release the peptides from the structural and functional constraints typically imposed on naturally occurring ribosomal peptides [21].

The overall mechanism of action of lantibiotic peptides can be phased into 3 steps, (1) binding of the peptide to the membrane, (2) insertion of the peptide into the membrane, (3) membrane permeabilization [22]. Lantibiotics show substantial specificity for some components (e. g., lipid II) of bacterial cell membranes, especially of gram-positive bacteria. Type A lantibiotics kill rapidly by pore formation, whereas Type B lantibiotics inhibit peptidoglycan biosynthesis [23]. Type A lantibiotics exert bactericidal activity toward a broad range of gram-positive bacterial strains, including Streptococci, Bacillus, Listeriae, Clostridia, and Staphylococci. The antibacterial effect is strong: The addition of $\mathrm{nM}$ concentrations of a lantibiotic is sufficient to kill bacterial cells. In contrast, other well-known antibacterial compounds, such as melittin, magainin, or cecropin, are active in mM concentrations [24].

Fungal cells, yeast cells, or human cells are very insensitive to lantibiotics, even when treated with $\mathrm{mM}$ concentrations of the peptides. 
In general, gram-negative bacteria are also insensitive to lantibiotics. It has been shown that their outer membrane functions as a barrier for the lantibiotics [25]. When the outer membrane of the gramnegative strains Escherichia coli or Salmonella species was weakened by treatment with ethylenediamine tetraacetic acid (EDTA) or osmotic shock, the susceptibility of the cells toward nisin or Pep5 strongly increased. The primary target for the activity of the lantibiotics appears to be the bacterial cytoplasmic membrane. The peptides interfere with the membrane function of sensitive cells by increasing the permeability of the bilayer for small molecules and disrupting the membrane potential, resulting in cell death. Furthermore, other mechanisms could be involved in their biological activity, since it has been reported that lantibiotics also inhibit outgrowth of bacterial spores, activate autolytic enzymes and might inhibit cell wall biosynthesis [26]. However, these mechanisms seem to be secondary effects, since these processes are relatively slow and require relatively high concentrations of lantibiotics.

Since the lantibiotics act on the bacterial cytoplasmic-membrane, they first have to pass the bacterial cell wall. Many non-lantibiotic bacteriocins, such as lactococcin appear to interact with membrane-associated receptor proteins, before their membrane perturbing activity. In contrast, a specific proteinaceous receptor for lantibiotic species on the outer surface of bacteria has not been found so far [27]. This study was designed to isolate the strains from hospital environment and to screen for the epidermin genes using traditional polymerase chain reaction (PCR).

\section{METHODS}

This study was conducted in the Department of Microbiology, Indian Academy Degree College. Sampling was done at 5 hospital premises (Poly Vista Clinic, Shree Vijay Laxmi Hospital, Cratis Hospital, Avhieta Hospital and Good Shepherd Hospital) in and around Bengaluru. About 10 samples were collected from each area and then cultured for isolation.

\section{Isolation of bacteria from the sample}

The samples were serially diluted with sterile distilled water and the tubes labeled as $10^{-3}$ and $10^{-4}$ are plated onto the Mueller Hinton Agar medium and then incubated at $37^{\circ} \mathrm{C}$ for $24 \mathrm{hrs}$. The colonies obtained were further subcultured to obtain pure colonies. The pure colonies obtained were used for the experimental study [28]

\section{Biochemical characterization}

Isolated bacteria were recultured and identified on basis of Bergey's Manual of Systematic Bacteriology. Gram staining and biochemical test such as indole test, sugar utilization test, methyl red test, citrate utilization Test, Voges-Proskauer test, starch hydrolysis, catalase test, and oxidase test were carried out to find the enzymatic activity of isolated organism [29].

\section{DNA isolation}

A volume of $2 \mathrm{ml}$ of culture was centrifuged at $8000 \mathrm{rpm}$, 10 minutes and the pellet formed was suspended in $567 \mu$ of TrisEDTA (TE) buffer. About $30 \mu \mathrm{l}$ of $10 \%$ safety data sheet and $3 \mu \mathrm{l}$ of $20 \mathrm{mg} / \mathrm{ml}$ proteinase $\mathrm{k}$ was added to the contents and mixed thoroughly and incubated for $1 \mathrm{hr}$ at $37^{\circ} \mathrm{C} .100 \mu \mathrm{l}$ of $5 \mathrm{M} \mathrm{NaCl}$ was added and mix thoroughly. The mixture was then added with $80 \mu \mathrm{l}$ hexadecyltrimethlyammonium bromide/ $\mathrm{NaCl}$ solution and incubated for 10 minutes at $65^{\circ} \mathrm{C}$. Following incubation, approximately equal volume (0.7-0.8 ml) of chloroform/isoamyl alcohol [24:1] was added and centrifuged for 8 minutes at $8000 \mathrm{rpm}$. The aqueous supernatant was transferred to a fresh tube and added with equal volume of phenol/chloroform/isoamyl alcohol [25:24:1] and the contents were spinned down in a microcentrifuge for 5 minutes. $0.6 \mu$ isopropanol was added to precipitate the DNA. The pellet was suspended in TE buffer until further use.

\section{PCR amplification}

The gene selected for the primer designing was epidermin gene with an amplicon size of $321 \mathrm{bp}$. The specific primers were designed using primer 3 plus software, and the designed oligonucleotides were synthesized in sigma corporation USA and ordered from Eurofins, Bangalore. The epi gene was amplified by PCR using purified genomic DNA as a template. Oligonucleotide primers were synthesized to amplify the intact region of epi gene. The forward primer, ATCGATAAGCCATCGCAAGA 3' and the reverse primer, 5' GTCGTTTGTCGAACATGTGG 3', were purchased from Eurofins, Bangalore. These primers correspond to the gene epi and thus, the final PCR product was $321 \mathrm{bp}$.

The PCR mixture comprised $\times 10$ reaction buffer with $\mathrm{MgCl} 2(1.5 \mathrm{mM})$, $2 \mu \mathrm{l}$ of dNTP mix $(2.5 \mathrm{mM}), 2 \mu \mathrm{l}$ each of forward and reverse primers (10 picomoles/ $\mu \mathrm{l}$ each primer), $0.3 \mu \mathrm{l}$ of Taq DNA polymerase $(5 \mathrm{U} / \mu \mathrm{l})$, and $50 \mathrm{ng} / \mu \mathrm{l}$ of template DNA in a total volume of $50 \mu \mathrm{l}$. The PCR was performed with the following cycling profile: Initial denaturation at $94^{\circ} \mathrm{C}$ for 2 minutes, followed by 35 cycles of 50 seconds denaturation at $94^{\circ} \mathrm{C}$, annealing at $55^{\circ} \mathrm{C}$ for 30 seconds, and extension at $72^{\circ} \mathrm{C}$ for 1 minute. The time for the final extension step was increased to 6 minutes. The PCR products amplified were then qualitatively analyzed on $1 \%$ agarose gel.

Table 1: Biochemical characteristics of the $\mathbf{1 0}$ isolates isolated from sample area 1

\begin{tabular}{|c|c|c|c|c|c|c|c|c|}
\hline Colony & Catalase & Oxidase & Indole & MR-VP & Citrate & Glucose fermentation & $\begin{array}{l}\text { Mannitol } \\
\text { fermentation }\end{array}$ & Organism \\
\hline PV1 & Negative & Negative & Negative & VP positive & Negative & $\begin{array}{l}\text { Gas formation and } \\
\text { color change }\end{array}$ & Negative & Aeromonas spp. \\
\hline PV2 & Negative & Negative & Negative & MR positive & Negative & Negative & $\begin{array}{l}\text { Gas formation and } \\
\text { color change }\end{array}$ & Staphylococcus aureus \\
\hline PV3 & Negative & Negative & Negative & VP positive & Negative & $\begin{array}{l}\text { Gas formation and } \\
\text { color change }\end{array}$ & Negative & Aeromonas spp. \\
\hline PV4 & Negative & Positive & Negative & VP positive & Negative & $\begin{array}{l}\text { Gas formation and } \\
\text { color change }\end{array}$ & Negative & Lactobacillus fermenti \\
\hline PV5 & Negative & Negative & Negative & MR positive & Negative & Negative & $\begin{array}{l}\text { Gas formation and } \\
\text { color change }\end{array}$ & Staphylococcus aureus \\
\hline PV6 & Negative & Negative & Negative & VP positive & Negative & Color change & Color change & Lactobacillus casei \\
\hline PV7 & Negative & Negative & Negative & MR positive & Negative & Negative & $\begin{array}{l}\text { Gas formation and } \\
\text { color change }\end{array}$ & Staphylococcus aureus \\
\hline PV8 & Negative & Positive & Negative & VP positive & Negative & $\begin{array}{l}\text { Gas formation and } \\
\text { color change }\end{array}$ & Negative & Lactobacillus fermenti \\
\hline PV10 & Negative & Negative & Negative & MR positive & Negative & Color change & Color change & Lactobacillus casei \\
\hline
\end{tabular}




\section{RESULTS AND DISCUSSION}

\section{Culture isolates}

The bacterial isolates obtained from different sampling areas were subcultured and identified based on their cultural characteristics. Both Gram-positive and Gram-negative strains were observed from the isolates. The biochemical characteristics obtained are shown in Tables 1-5 and were identified and labeled.

\section{PCR amplification}

A total of 21 bacterial cultures were selected and screened, their genomic DNA isolated and amplified through PCR (Fig. 1). Of the
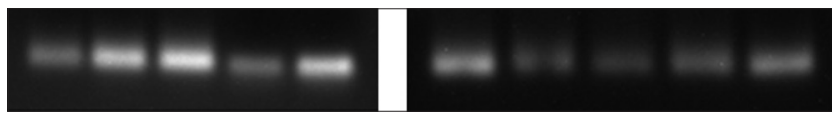

Fig. 1: Left: Gel showing the polymerase chain reaction amplification of epi gene on $2 \%$ agarose gel. Molecular marker (100 bp) is used. Lane 1: Staphylococcus aureus, Lane 2: Lactobacillus fermenti, Lane 3: Streptococcus sp. Lane 4: Lactobacillus casei, Lane 5: Bacillus badius; Right: Lane 1: Bacillus larvae, Lane 2: S. aureus, Lane 3: Bacillus popilliae, Lane 4: Bacillus megaterium, Lane 5: Bacillus sp
21 bacterial samples, only 10 showed positive amplification towards epidermin gene which are (Staphylococcus aureus, Lactobacillus fermenti, Streptococcus sp., Lactobacillus casei, Bacillus badius, Bacillus larvae, S. aureus, B. popilliae, Bacillus megaterium, Bacillus sp.). From 10 bacterial cultures, 5 organisms showed maximum amplification for epidermin gene (L. fermenti, Streptococcus sp., B. badius, B. larvae, Bacillus sp.)

\section{DISCUSSION}

Antibiotic resistance in bacteria is high and is increasing in many countries worldwide causing great concern for public health [30]. During the past decade, there have been an increasing number of reports both antibiotic and antibiotic resistance genes in different environmental settings. Antibiotic resistant bacteria and genes encoding antibiotic resistance are commonly detected in wastewater, often at higher rates and concentrations compared to surface water [31]. Wastewater can also provide favorable conditions for the growth of a diverse bacterial community, which constitutes a basis for the selection and spread of antibiotic resistance. Wastewater samples were collected and organisms were isolated which are process for DNA isolation without any contamination of RNA. Further, it is processed for PCR amplification. A total of 21 samples were processed for PCR

Table 2: Biochemical characteristics of the $\mathbf{1 0}$ isolates isolated from sample area 2

\begin{tabular}{|c|c|c|c|c|c|c|c|c|}
\hline Colony & Catalase & Oxidase & Indole & MR-VP & Citrate & Mannitol fermentation & Starch hydrolysis & Organism \\
\hline SVL1 & Negative & Positive & Negative & MR positive & Negative & Negative & Positive & Bacillus hadius \\
\hline SVL2 & Negative & Positive & Negative & VP positive & Negative & Negative & Negative & Bacillus larvae \\
\hline SVL3 & Negative & Positive & Negative & MR positive & Negative & Negative & Positive & Bacillus hadius \\
\hline SVL4 & Negative & Negative & Negative & VP positive & Positive & Negative & Positive & Bacillus licheniformis \\
\hline SVL5 & Negative & Negative & Negative & VP positive & Negative & Negative & Positive & Bacillus pohmyxa \\
\hline SVL 6 & Negative & Positive & Negative & VP positive & Negative & Color change & Negative & Bacillus larvae \\
\hline SVL7 & Negative & Positive & Negative & VP positive & Positive & Negative & Positive & Bacillus coagulans \\
\hline SVL9 & Negative & Negative & Negative & MR positive & Positive & Negative & Positive & Bacillus megaterium \\
\hline SVL10 & Negative & Positive & Negative & MR positive & Positive & Negative & Negative & Bacillus azotoformans \\
\hline
\end{tabular}

MR: Methyl red, VP: Voges-Proskauer, SVL: ???

Table 3: Biochemical characteristics of the 10 isolates isolated from sample area 3

\begin{tabular}{|c|c|c|c|c|c|c|c|c|}
\hline Colony & Catalase & Oxidase & Indole & MR-VP & Citrate & Mannitol fermentation & Starch hydrolysis & Organism \\
\hline CR1 & Negative & Positive & Negative & VP positive & Positive & Negative & Positive & Bacillus coagulans \\
\hline CR2 & Negative & Positive & Negative & VP positive & Positive & Negative & Negative & Bacillus azotoformans \\
\hline CR3 & Negative & Positive & Negative & VP positive & Negative & Colour change & Negative & Streptococcus spp. \\
\hline CR4 & Negative & Negative & Negative & VP positive & Negative & Negative & Positive & Bacillus sp. \\
\hline CR5 & Negative & Positive & Negative & VP positive & Positive & Negative & Positive & Bacillus coagulans \\
\hline CR6 & Negative & Positive & Negative & VP positive & Positive & Negative & Positive & Bacillus coagulans \\
\hline CR7 & Negative & Positive & Negative & VP positive & Positive & Negative & Positive & Bacillus coagulans \\
\hline CR8 & Negative & Negative & Negative & VP positive & Negative & Negative & Negative & Bacillus sp. \\
\hline CR9 & Negative & Positive & Negative & MR positive & Positive & Negative & Negative & Bacillus azotoformans \\
\hline CR10 & Negative & Positive & Negative & VP positive & Positive & Negative & positive & Bacillus coagulans \\
\hline
\end{tabular}

MR: Methyl red, VP: Voges-Proskauer, CR: ???

Table 4: Biochemical characteristics of the $\mathbf{1 0}$ isolates isolated from sample area 4

\begin{tabular}{|c|c|c|c|c|c|c|c|c|c|}
\hline Colony & Catalase & Oxidase & Indole & MR-VP & Citrate & $\begin{array}{l}\text { Glucose } \\
\text { fermentation }\end{array}$ & $\begin{array}{l}\text { Mannitol } \\
\text { fermentation }\end{array}$ & $\begin{array}{l}\text { Starch } \\
\text { hydrolysis }\end{array}$ & Organism \\
\hline AVI & Negative & Negative & Negative & VP positive & Negative & Negative & Negative & Negative & Bacillus sp. \\
\hline AV2 & Negative & Positive & Negative & VP positive & Negative & Color change & Negative & Negative & Aeromonas spp. \\
\hline AV3 & Negative & Negative & Negative & MR positive & Negative & Negative & Negative & Negative & Bacillus popilliae \\
\hline AV4 & Negative & Positive & Negative & VP positive & Negative & Negative & color change & Positive & Lactobacillus casei \\
\hline AV5 & Negative & Negative & Negative & VP positive & Negative & Negative & Negative & Positive & Bacillus polymyxa \\
\hline AV6 & Negative & Positive & Negative & VP positive & Negative & Negative & Negative & Positive & Streptococcus sp. \\
\hline AY8 & Negative & Negative & Negative & MR positive & Negative & Negative & Negative & Positive & Bacillus badius \\
\hline AY9 & Negative & Positive & Negative & MR positive & Positive & Negative & Negative & Positive & Bacillus megaterium \\
\hline AV10 & Negative & Negative & Negative & MR positive & Positive & Negative & Negative & Negative & Bacillus azotoformans \\
\hline
\end{tabular}

MR: Methyl red, VP: Voges-Proskauer, AV: ??? 
Table 5: Biochemical characteristics of the $\mathbf{1 0}$ isolates isolated from sample area 5

\begin{tabular}{|c|c|c|c|c|c|c|c|c|}
\hline Colony & Catalase & Oxidase & Indole & MR-VP & Citrate & Glucose fermentation & Mannitol fermentation & Organism \\
\hline GS1 & Negative & Negative & Negative & VP positive & Negative & Color change & Color change & Streptococcus sp. \\
\hline GS2 & Negative & Negative & Negative & MR positive & Negative & Color change & Color change & Aeromonas spp. \\
\hline GS3 & Negative & Negative & Negative & MR positive & Negative & Color change & Color change & Aeromonas spp. \\
\hline GS4 & Negative & Positive & Negative & VP positive & Negative & Color change & Color change & Aeromonas sobria \\
\hline GS5 & Negative & Negative & Negative & VP positive & Negative & Color change & Color change & Streptococcus spp. \\
\hline GS6 & Negative & Positive & Negative & MR positive & Negative & Color change & Color change & Lactobacillus casei \\
\hline GS7 & Negative & Positive & Negative & MR positive & Negative & Color change & Color change & Lactobacillus casei \\
\hline GS9 & Negative & Positive & Negative & MR positive & Negative & Color change & Color change & Lactobacillus casei \\
\hline GS10 & Negative & Positive & Negative & MR positive & Negative & Color change & Color change & Lactobacillus casei \\
\hline
\end{tabular}

MR: Methyl red, VP: Voges-Proskauer, GS: ???

amplification out of which 10 isolates showed positive amplification. Totally 5 organisms gave maximum amplification for epidermin gene. Some bacterial samples may not have the epidermin gene which does not show amplification this confers that the epidermin gene is absent in certain organisms. Further the experiment can be planned to purify the compound of interest and use it as an antibacterial against certain gram-positive organisms.

\section{REFERENCES}

1. Kaplan N, Albert M, Awrey D, Bardouniotis E, Berman J, Clarke T, et al. Mode of action, in vitro activity, and in vivo efficacy of AFN1252, a selective antistaphylococcal FabI inhibitor. Antimicrob Agents Chemother 2012;56:5865-74.

2. Karlowsk JA, Laing NM, Baudry T, Kaplan N, Vaughan D, Hoban DJ, et al. In vitro activity of API-1252, a novel FabI inhibitor, against clinical isolates of Staphylococcus aureus and Staphylococcus epidermidis. Antimicrob Agents Chemother 2007;51:1580-1.

3. Francius G, Domenech O, Mingeot-Leclercq MP, Dufrêne YF. Direct observation of Staphylococcus aureus cell wall digestion by lysostaphin. J Bacteriol 2008;190(24):7904-9.

4. Raja AF, Ali F, Khan IA, Shawl AS, Arora DS, Shah BA, et al. Antistaphylococcal and biofilm inhibitory activities of acetyl-11-keto-bboswellic acid from Boswellia serrate. BMC Microbiol 2011;11:54-67.

5. Ilić D, Damljanović I, Stevanović D, Vukićević M, Blagojević P, Radulović N, et al. Sulfur-containing ferrocenyl alcohols and oximes: New promising antistaphylococcal agents. Chem Biodivers 2012;9(10):2236-56.

6. Jørgensen NO, Brandt KK, Nybroe O, Hansen M. Delftia lacustris sp. Nov., A peptidoglycan degrading bacterium from fresh water, and emended description of Delftia tsuruhatensis as a peptidoglycandegrading bacterium. Int J Syst Evol Microbiol 2009;59:2195-9.

7. Ackerley DF, Caradoc-Davies TT, Lamont IL. Substrate specificity of the nonribosomal peptide synthetase PvdD from Pseudomonas aeruginosa. J Bacteriol 2003;185(9):2848-55

8. Sieber SA, Marahiel MA. Learning from nature's drug factories: Nonribosomal synthesis of macrocyclic peptides. J Bacteriol 2003;185(24):7036-43.

9. Felnagle EA, Jackson EE, Chan YA, Podevels AM, Berti AD, McMahon MD, et al. Nonribosomal peptide synthetases involved in the production of medically relevant natural products. Mol Pharm 2008:5(2):191-211

10. Ibrahima A, Yangb L, Johnstonc C, Liud X, Mab B, Magarvey NA. Dereplicating nonribosomal peptides using an informatics search algorithm for natural products (iSNAP) discovery. Proc Natl Acad Sci 2012;109(47):19196-201.

11. Bierbaum G, Sahl HG. Lantibiotics: Mode of action, biosynthesis and bioengineering. Curr Pharm Biotechnol 2009;10(1):2-18.

12. Staunton J, Weissman KJ. Polyketide biosynthesis: A millennium review. Nat Prod Rep 2001;18(4):380-416.

13. Park HS, Yoon YM, Jung SJ, Kim CM, Kim JM, Kwak JH. Antistaphylococcal activities of CG400549, a new bacterial enoylacyl carrier protein reductase (FabI) inhibitor. J Antimicrob Chemother 2007;60(3):568-74.

14. Haste NM, Hughes CC, Tran DN, Fenical W, Jensen PR, Nizet V, et al. Pharmacological properties of the marine natural product marinopyrrole A against methicillin-resistant Staphylococcus aureus. Antimicrob Agents Chemother 2011;55(7):3305-12.
15. Bordignon SE, Gatti DJ. Antagonistic activity of lactic acid bacteria isolated from artisan Italian salami. Braz J Food Technol Camp 2010;13(1):18-22

16. Sathish SR, Kokati VB. In-vitro antimicrobial activity of marine actinobacteria against multidrug resistance Staphylococcus aureus. Asian Pac J Trop Biomed 2012;2(10):787-92

17. Sheikh HM. Antimicrobial activity of certain bacteria and fungi isolated from soil mixed with human saliva against pathogenic microbes causing dermatological diseases. Saudi J Biol Sci 2010;17(4):331-9.

18. Wyatt MA, Lee J, Ahilan Y, Magarvey NA. Bioinformatic evaluation of the secondary metabolism of antistaphylococcal environmental bacterial isolates. Can J Microbiol 2013;59(7):465-71.

19. Thompson JM, Gündoğdu A, Stratton HM, Katouli M. Antibiotic resistant Staphylococcus aureus in hospital wastewaters and sewage treatment plants with special reference to methicillin-resistant Staphylococcus aureus (MRSA). J Appl Microbiol 2013;114(1):44-54

20. Caboche S, Pupin M, Leclère V, Fontaine A, Jacques P, Kucherov G. NORINE: A database of nonribosomal peptides. Nucleic Acids Res. 2008;36:D326-31.

21. McLaughlin RE, Ferretti JJ, Hynes WL. Nucleotide sequence of the streptococcin A-FF22 lantibiotic regulon: Model for production of the lantibiotic SA-FF22 by strains of Streptococcus pyogenes. FEMS Microbiol Lett 1999;175:171-7.

22. Rajan V, Kumar VG, Gopal S. A cfr-positive clinical staphylococcal isolate from India with multiple mechanisms of linezolid-resistance. Indian J Med Res 2014;139(3):463-7.

23. Thati V, Shivannavar CT, Gaddad SM. Vancomycin resistance among methicillin resistant Staphylococcus aureus isolates from intensive care units of tertiary care hospitals in Hyderabad. Indian J Med Res 2011;134(5):704-8.

24. van de Kamp M, van den Hooven HW, Konings RN, Bierbaum G, Sahl HG, Kuipers OP, et al. Elucidation of the primary structure of the lantibiotic epilancin K7 from Staphylococcus epidermidis K7. Cloning and characterisation of the epilancin-K7-encoding gene and NMR analysis of mature epilancin K7. Eur J Biochem 1995;230(2):587-600.

25. Piper C, Casey PG, Hill C, Cotter PD, Ross RP. The lantibiotic lacticin 3147 prevents systemic spread of Staphylococcus aureus in a murine infection model. Int J Microbiol 2012;2012:806230.

26. Tenover FC, Biddle JW, Lancaster MV. Increasing resistance to vancomycin and other glycopeptides in Staphylococcus aureus. Emerg Infect Dis 2001;7(2):327-32.

27. Kruszewska D, Sahl HG, Bierbaum G, Pag U, Hynes SO, Ljungh A. Mersacidin eradicates methicillin-resistant Staphylococcus aureus (MRSA) in a mouse rhinitis model. J Antimicrob Chemother 2004:54(3):648-53.

28. Pyar H, Peh KK. Characterization and identification of Lactobacillus acidophilus using biolog rapid identification system. Int J Pharm Pharm Sci 2014;6(1):189-93.

29. Soni S, Soni UN. In-vitro anti-bacterial and anti-fungal activity of select essential oils. Int J Pharm Pharm Sci 2014;6(6):586-91.

30. Hiron A, Falord M, Valle J, Débarbouillé M, Msadek T. Bacitracin and nisin resistance in Staphylococcus aureus: A novel pathway involving the BraS/BraR two-component system (SA2417/SA2418) and both the $\mathrm{BraD} / \mathrm{BraE}$ and $\mathrm{VraD} / \mathrm{VraE} \mathrm{ABC}$ transporters. Mol Microbiol 2011;81(3):602-22

31. Daly KM, Upton M, Sandiford SK, Draper LA, Wescombe PA, Jack RW, et al. Production of the BSA lantibiotic by community-acquired Staphylococcus aureus strains. J Bacteriol 2010;192(4):1131-42. 